\title{
Identification of Zygotic and Nucellar Individuals Produced from Several Citrus Crosses Using SSRs Markers
}

\author{
Ercan YILDIZ ${ }^{*}$, Mustafa KAPLANKIRAN², Turan Hakan \\ DEMIIRKESER ${ }^{2}$, Aydın UZUN ${ }^{3}$, Celil TOPLU² \\ ${ }^{1}$ University of $U_{\xi}$ sak, Faculty of Agriculture and Natural Sciences, Department of Horticulture, \\ Usak,Turkey; ercanyildiz54@gmail.com (corresponding author) \\ ${ }^{2}$ University of Mustafa Kemal, Faculty of Agriculture, Department of Horticulture, Antakya, Hatay, Turkey \\ ${ }^{3}$ University of Erciyes, Faculty of Agriculture, Department of Horticulture, Kayseri, Turkey
}

\begin{abstract}
Turkey is an important citrus-producing country. However, new cultivars are needed to sustain citrus production and ensure its competitiveness against other crops. There are currently several citrus breeding programs that aim to help overcome the lack of local commercial varieties and to contribute to Turkey's competitive capacity in the citrus market. In this study, we report the utilization of molecular markers in one such breeding program. Simple sequence repeat (SSR) markers were employed to eliminate nucellar individuals from a hybrid population produced by crossing. The crosses included 'Fremont' and 'Robinson' mandarins as the female parents and 'Midknight Valencia,, 'Rhode Red Valencia', and 'Valencia Late' oranges and 'Rio Red' grapefruit cultivars as the male parents. Seedlings with the same banding patterns as the female parent were identified as nucellar seedlings by 11 SSR primers. Primers AG14 and TAA03 were found to be more effective at identifying zygotic individuals than other primers. 'Fremont' and 'Robinson' mandarins produced $36.91 \%$ and $31.09 \%$ of nucellar seedlings, respectively. As a pollen parent, 'Rio Red' grapefruit had a higher ratio of zygotic seedlings compared to 'Midknight Valencia', and can be recommended in breeding programs. Comparative analysis of different citrus fruits in the breeding programs allowed us to design an efficient hybridization scheme for this study.
\end{abstract}

Key words: breeding, pollen parent, nucellar seedling, molecular marker

\section{Introduction}

Citrus, a major fruit crop, is grown throughout the tropical and subtropical regions of the world. Most of the citrus cultivars have resulted from natural hybridization and mutation (Hodgson, 1967). Most citrus breeding programs have relied mainly on classical breeding practices, which are based on making controlled crossings and selecting superior individuals. One of the major problems of the classical breeding programs when using these cultivars as a seed parent is polyembryony, when one seed may contain two or more embryos of zygotic or nucellar origin (Soost and Roose, 1996). Nucellar embryony, which occurs commonly in citrus species, creates a serious problem for cross breeding studies as it produces a large number of asexual embryos, greatly limiting the genetic variability obtained by controlled pollination. In a seed, adventive (extra) embryos that develop almost entirely from nucellus cells contain the same genetic material as the mother plant and can create a number of problems. Firstly, most polyembryonic cultivars produce only a small number of crosses. Secondly, it is often difficult to distinguish nucellar and zygotic seedlings at an early stage (De Lange and
Vincent, 1977). However, discrimination of nucellar seedlings at an early stage is essential to avoid the 5-10 years of expense that accompany the unwarranted growth and maintenance of nucellar seedlings that are genetically identical to seed parents .

Polyembryony is caused by a number of factors including the type of pollinator, the amount and viability of available pollen, plant nutrition, air temperature, environmental and soil humidity, and wind speed (Spiegel-Roy et al., 1977; Nishiura and Iwasaki, 1980; Soost et al., 1980; Nakatani et al., 1984; Khan and Roose, 1988; Moore and Castle, 1988; Roose and Traugh, 1988; Soares-Filho et al., 1995). Dhillon et al. (1993) reported that adventitious embryos developed into globular or early cotyledon stages in the absence of pollination, but that the embryos required the endosperm in order to grow, making pollination and fertilization necessary for the development of the polyembryonic seeds. Consequently, some factors that influence pollination, fertilization or seed development will also affect the percentage of polyembryony and embryo number per seed. Garcia et al. (1999) suggested that when the zygotic embryo is a hybrid, it may be more vigorous and compete better with nucellar embryos, whereas zygot- 
ic embryos produced by self-pollination are less vigorous and may not be competitive with nucellar embryos.

Many studies aimed at separating the different types and varieties of citrus, as well as those aimed at separating nucellar and zygotic plants, started by utilizing morphological characterization (Furr and Reece, 1946; Cameron, 1979), spectrophotometer (Pieringer and Edwards, 1967) and chromatography techniques (Albach and Redman, 1969; Stanley and Jurd, 1971; Tatum et al., 1974; Weinbaum et al., 1982). Several biochemical methods, including enzymatic darkening due to polyphenols (Esen and Soost, 1974), have also been used. None of these methods efficiently confirmed the identity of true nucellar seedlings (Ruiz et al., 2000; Tusa et al., 2002). Later, isozymes were employed in plant breeding (Iglesias et al., 1974; Moore and Castle, 1988; Ashari et al., 1988; Anderson et al., 1991). Nevertheless, because products of gene expression were used in those cases, results may be influenced by the environment or by the developmental stage of the plant and its organs, thus making this method unreliable for zygotic seedling identification. Recently, molecular marker techniques have been improved, enabling more specific and precise studies to be conducted. These new techniques are particularly advantageous for woody plants as they allow selection in much shorter time periods than previously possible.

The use of DNA polymorphisms for the identification of hybrid seedlings is important in citrus breeding programs as it accelerates the process of progeny screening. Among DNA-based methods, random amplified polymorphic DNA (RAPD) analysis is one of the most widely used for differentiating hybrids in citrus breeding programs (Bastianel et al., 1998; Vilarinhos et al., 2000). A number of recent studies have also described the use of SSR markers as an alternate method to distinguish sexual from nucellar citrus seedlings (Mullis et al., 1986; Ruiz et al., 2000; Oliveira et al., 2002; Rao et al., 2008; Shareefa et al., 2009).

In this report, we describe the identification of nucellar individuals within a population composed of $F_{1}$ populations of different citrus species and cultivars based on the analysis using SSR markers.

\section{Materials and methods}

\section{Plant material}

Controlled pollinations with pollens into flowers of trees growing in the Mustafa Kemal University experimental farm in Dörtyol, Hatay, Turkey $\left(36^{\circ} 09^{\prime} \mathrm{E}, 36^{\circ} 51^{\prime} \mathrm{N}\right.$; altitude of $9 \mathrm{~m}$ ) were conducted at full bloom. For crossing, the flowers of the balloon stage in the clusters of the mother parents were selected, and the others remained properly to avoid pollen contamination. Emasculation of male parts of the flowers was done with forceps carefully to avoid any injury of the stigma, and the all previously opened flowers and small, immature buds were removed manually. Stigmas were hand-pollinated with anthers from freshly opened flowers by a drawing brush. Immediately after pollination, the pollinated flowers were covered with cotton bags. Each pollination treatment was applied to flowers on three trees (about 100 flowers per treatment). The crossed flowers were marked with tag and tagging was continued up to harvesting of fruit, developed from crossing. Bags were removed 2 weeks after pollination. Fruits were harvested at maturity in the first week of December for Robinson cultivar, in the mid-December for Fremont cultivar and all fruits were individually weighed and seeds extracted. The mandarin cultivars 'Fremont' and 'Robinson' were used as female parents, and the orange cultivars 'Valencia Late', 'Midknight Valencia' and 'Rhode Red Valencia' with 'Rio Red' grapefruit were used as male parents.

A total of 500 seedlings were produced as a result of these crosses. For DNA extracting, the leaves were collected from seedlings with 9 months old.

\section{DNA extraction and SSR analysis}

Genomic DNA was extracted from young leaves using the CTAB method modified by Doyle and Doyle (1990). A total of 11 SSR primers (Tab. 1), as previously described by Kijas et al. (1997), were used to amplify the DNA. Polymerase chain reaction (PCR) amplifications were performed as described by Gulsen et al. (2005) with minor modifications. Each $15 \mu \mathrm{L}$ amplification reaction consisted of $0.2 \mu \mathrm{g} / \mu \mathrm{L}$ BSA (bovine serum albumin), $200 \mu \mathrm{M}$ total dNTP, $2.5 \mathrm{mM} \mathrm{MgCl} 2,1.33 \mathrm{mM}$ each primer, $1 \mathrm{U}$ of Platinum Taq polymerase (Invitrogen), $4.3 \mu \mathrm{L} \mathrm{ddH2O}$ and 20 ng DNA template. Amplification was performed in a DNA thermal cycler (Sensoquest Progen Scientific Ltd. Mexborough, South Yorkshire, UK) under the following conditions: 2 min at $94^{\circ} \mathrm{C}$, followed by 5 cycles at $94^{\circ} \mathrm{C}$ for $1 \mathrm{~min}, 35^{\circ} \mathrm{C}$ for $1 \mathrm{~min}, 72^{\circ} \mathrm{C}$ for $1 \mathrm{~min}$, followed by 35 cycles for $1 \mathrm{~min}$ at $94^{\circ} \mathrm{C}, 1 \mathrm{~min}$ at $50^{\circ} \mathrm{C}$ and a final extension at $72^{\circ} \mathrm{C}$ for $1 \mathrm{~min}$.

PCR products were mixed with $3 \mu \mathrm{L} 5 \mathrm{x}$ loading buffer $(20 \mathrm{~mL}$ (40\%) glycerol, 0.05 g Bromophenol Blue, 30 $\mathrm{mL} \mathrm{ddH2O}$ ) and analyzed by electrophoresis in $2 \%$ agarose gels under nondenaturing conditions in $1 \mathrm{x}$ TBE buffer $(89 \mathrm{mM}$ Tris borate, $89 \mathrm{mM}$ boric acid, $2 \mathrm{mM}$ EDTA, $\mathrm{pH} 8.3$ and $25 \mu \mathrm{L}(10 \mathrm{mg} / \mathrm{mL})$ ethidium bromide). Five $\mu \mathrm{l}$ of $100 \mathrm{bp}$ DNA ladder was used as size marker (Biorun, Nantes, France). Electrophoresis was also carried out on $10 \%$ PAGE $(20 \times 20 \mathrm{~cm})$, at $115 \mathrm{~V}$ for $3 \mathrm{~h}$. To identify hybrid and nucellar seedlings, DNA polymorphisms were analyzed by comparing the SSR markers produced by these seedlings with those generated by the parents.

\section{Data analysis}

Each band was scored as present (1) or absent (0), and data were analyzed with the Numerical Taxonomy Multivariate Analysis System (NTSYS-pc) software package (Rohlf, 1993). A similarity matrix was constructed based 
Tab. 1. SSR primer sequences used to identify zygotic Citrus progeny

\begin{tabular}{|c|c|c|c|}
\hline No & Primer & \multicolumn{2}{|c|}{ Sequence } \\
\hline 1 & TAA1 & 5'-GACAACATCAACAACAGCAAGAGC & 3'-AAGAAGAAGAGCCCCCATTAGC \\
\hline 2 & TAA3 & 5'-AGAGAAGAAACATTTGCGGAGC & 3'-GAGATGGGACTTGGTTCATCACG \\
\hline 3 & TAA41 & 5'AGGTCTACATTGGCATTGTC & 3'-ACATGCAGTGCTATAATGAATG \\
\hline 4 & TAA45 & 5'-GCACCTTTTATACCTGACTCGG & 3'-TTCAGCATTTGAGTTGGTTACG \\
\hline 5 & TAA52 & 5'-GATCTTGACTGAACTTAAAG & 3’ATGTATTGTGTTGATAACG \\
\hline 6 & AG14 & 5'AAAGGGAAAGCCCTAATCTCA & 3'-СTTCCTCTTGCGGAGTGTTC \\
\hline 7 & ATC09 & 5'-TTCСТTATGTAATTGCTCTTTG & 3'-TGTGAGTGTTTGTGCGTGTG \\
\hline 8 & CAC33 & 5’-GGTGATGCTGCTACTGATGC & 3'-CAATTGTGAATTTGTGATTCCG \\
\hline 9 & CAGG9 & 5'AATGCTGAAGATAATCCGCG & 3'-TGCCTTGCTCTCСАСТCC \\
\hline 10 & СAT01 & 5'-GCTTTCGATCCCTCCACATA & 3'-GATCCCTACAATCCTTGGTCC \\
\hline 11 & СТ02 & 5'ACGGTGCGTTTTGAGGTAAG & 3'-TGACTGTTGGATTTGGGATG \\
\hline
\end{tabular}

on Dice's coefficient (Dice, 1945), which considers only one-to-one matches between two taxa for similarity.

\section{Results and discussion}

Zygotic seedlings were determined by the presence of bands amplified specifically in the pollen parent from PCR using the 11 primers. Among the $233 \mathrm{~F}_{1}$ plants obtained from the crosses with 'Fremont' mandarin as the female parent, 86 seedlings (36.91\%) were identified as nucellar seedlings (Tab. 2). For 'Robinson' mandarin as the female parent, this ratio was $31.09 \%$ (83 nucellar seedlings out of $267 \mathrm{~F}_{1}$ plants). Various levels of zygotic seedlings have also been observed in other citrus species and crosses. Frost and Soost (1967) reported zygotic frequencies of $78.7 \%$ and $14.0 \%$ for 'King' and 'Willowleaf' tangerines, respectively, using pollen from Poncirus trifoliata. Hearn (1973) reported that the selection of 'Mediterranean Sweet' orange produced $32 \%$ monoembryonic seeds and $62 \% \mathrm{zy}-$ gotic seedlings when P. trifoliata pollen was used. Soost et al. (1980) found a zygote frequency of approximately $85 \%$ using 'King' as the female parent and pollen from 'Parson Special' tangerine. Several studies have shown that zygote frequency does not exceed $15 \%$, depending on the species, and in some cases, only nucellar individuals are obtained (Cameron and Soost, 1980; Hirai et al., 1986; Ashari et al., 1988; Roose and Traugh, 1988). These results were similar to those reported by Moore and Castle (1988), who identified 24\% zygotic 'Volkameriana' lemon seedlings using isoenzyme based markers. Hwang and Yeuh (1989) reported zygotic frequencies of $42.8 \%$ and $66.7 \%$ for 'Tankan' mandarin, using pollen from sour orange and $P$. trifoliata, respectively. Also, the authors reported a zygote frequency from $2.7 \%$ to $10.7 \%$ using 'Tankan' mandarin as the female parent and pollen from different orange cultivars. Hwang (1991) suggested that zygotic seedlings were identified by leaf morphology. He obtained $73 \%$ zygotic seedlings from 'Eureka' lemon crossed by trifoliate orange, and $38 \%$ to $56 \%$ zygotic seedlings from 'Eureka' and 'Lisbon' lemon cultivars crossed by sweet orange. Cristofani and
Machado (1998) reported 6\% zygotic seedlings of 'Cravo' lemon in a sample of 50 plants taken from a population of 576 produced in a greenhouse using RAPD markers. Bastianel et al. (1998) using RAPD, identified 26.7\% hybrid seedlings from crossing 'Montenegrina' with 'King' tangerine species. For C. volkameriana rootstock, Garcia et al. (1999) reported only $22 \%$ zygotic seedlings from seeds derived from open pollination, and $60 \%$ of zygotic seedlings were obtained after pollination with $P$. trifoliata. Ruiz et al. (2000), using SSRs, classified $86.95 \%$ hybrid seedlings from crossing 'Flying Dragon' and 'Ortanique' tangor. Yun et al. (2007) obtained $0.0 \%$ to $13.4 \%$ hybrid seedlings from crossing female parents 'Miyagawa Wase', 'Okitsu Wase' and 'Shiranuhi' mandarins, and 'Ponkan' mandarin and 'Swingle' citrumelo male parents. Rao et al. (2008) crossed different mandarin and pummelo cultivars to obtain alternative rootstock towards sour orange and, using SSRs, identified 22.2\% hybrid seedlings from these crosses. Garcia et al. (1999) suggested that zygotic embryos produced by self-pollination are less vigorous and may not be competitive with nucellar ones. The percentages of zygotic progenies in various citrus hybrids have been found to depend on the seed parent used (Spiegel-Roy et al., 1977), the pollen origin (Cameron and Soost, 1980; Soares-Filho et al., 1995), and environmental influences (Khan and Roose, 1988; Moore and Castle, 1988; Roose and Traugh, 1988).

In this study, using both 'Fremont' and 'Robinson' mandarin cultivars as the female parents produced the highest hybrid seedling ratio when 'Rio Red' cultivar was used as the male parent. The lowest hybrid seedling ratio was obtained when 'Midknight Valencia' pollen was used. When 'Fremont' and 'Robinson' mandarin cultivars were used as female parents with 'Rio Red' cultivar as the male parent, there was a significantly higher zygotic individual ratio in the $\mathrm{F}_{1}$ population. When considering the whole $F_{1}$ population, the use of 'Midknight Valencia' as the male parent increased the nucellar seedling ratio to a greater extent than other orange male parents. Therefore, 'Mid- 
knight Valencia' was not found to be useful for hybridization.

Tab. 2. Frequency of nucellar seedling obtained by controlled pollination with viable pollens from different orange and grapefruit cultivars in 'Fremont' and 'Robinson' mandarins

\begin{tabular}{|ccccccc}
\hline & \multicolumn{3}{c}{ Fremont } & \multicolumn{3}{c}{ Robinson } \\
\hline $\begin{array}{c}\text { Female } \\
\text { parents }\end{array}$ & $\begin{array}{c}\text { No of } \\
\text { seedling }\end{array}$ & $\begin{array}{c}\text { Nucellar } \\
\text { seedling } \\
\text { No }\end{array}$ & $\begin{array}{c}\text { Percent } \\
\text { No of }\end{array}$ & \multicolumn{2}{c}{ Nucellar seedling } \\
\hline $\begin{array}{c}\text { Valencia } \\
\text { Late }\end{array}$ & 63 & 24 & 38.10 & 77 & 25 & 32.47 \\
\hline $\begin{array}{c}\text { Rhode Red } \\
\text { Valencia }\end{array}$ & 85 & 32 & 37.65 & 79 & 28 & 35.44 \\
$\begin{array}{c}\text { Midknight } \\
\text { Valencia }\end{array}$ & 44 & 18 & 40.91 & 24 & 13 & 54.17 \\
\hline Rio Red & 41 & 12 & 29.27 & 87 & 17 & 19.54 \\
\hline Total & 233 & 86 & 36.91 & 267 & 83 & 31.09 \\
\hline
\end{tabular}

The seedlings of each parental combination were assessed using SSR primers. Whereas some individuals were tested to be either either zygotic or nucellar using only one SSR primer, others were tested using more than one SSR marker. In combinations where the 'Fremont' mandarin was used as the female parent, the TAA41 primer was able to identify more zygotic individuals (47) than the other primers used (Tab. 3).

Also, in combinations where the 'Robinson' mandarin was used as the female parent, AG14 and TAA03 primers determined 59 and 58 zygotic individuals, respectively. In contrast, the CAT01, TAA01 and TAA45 primers (when 'Fremont' mandarin was used as female parent) and TAA45 and TAA52 (when 'Robinson' mandarin was used as female parent) were not useful in determining the identity of zygotic seedlings. When the whole $\mathrm{F}_{1}$ population was considered, the AG14 and TAA03 primers were found to be more effective than other primers at distinguishing zygotic individuals, whilst the TAA45 primer was not able to identify zygotic seedlings. When a population is derived from a cross, all of the zygotic individuals show a genotype different from that of the mother at any discriminating locus, provided that the father has alleles different than those of the mother (Ruiz et al., 2000). Of the 24 seedlings coming from the combination of 'Robinson' mandarin as the female parent and 'Midknight Valencia' orange as male parent, five seedlings showed a banding pattern different from that of the mother plant when the TAA03 primer was used (Fig. 1).

Previous studies have indicated that the Citrus genus can be classified into three main groups as mandarin $(C$. reticulata), pummelo (C. grandis) and citron (C. medica). These studies made with isoenzyme (Asins et al., 1996), SSR marker (Luro et al., 2000) and sequence related amplified polymorphism (SRAP) marker (Uzun et al., 2009). The other citrus species such as lemon, orange, and grapefruit are derivatives from these three ancestral species (Nicolosi et al., 2000; Gulsen and Roose, 2001). The literature suggested that orange and mandarin were in the same group as shown in studies using isoenzyme (Novelli et al., 2000), SSR marker (Barkley et al., 2006) and AFLP marker (Pang et al., 2007).

Tab. 3. Number of zygotic individuals in several crossing populations tested using different SSR primers

\begin{tabular}{|c|c|c|c|c|c|c|c|c|c|}
\hline \multirow[b]{2}{*}{ Primer } & \multicolumn{4}{|c|}{ Fremont } & \multicolumn{4}{|c|}{ Robinson } & \multirow[b]{2}{*}{ Total } \\
\hline & $\begin{array}{c}\text { Valencia } \\
\text { Late }\end{array}$ & $\begin{array}{c}\text { Rhode Red } \\
\text { Valencia }\end{array}$ & $\begin{array}{l}\text { Midknight } \\
\text { Valencia }\end{array}$ & Rio Red & $\begin{array}{c}\text { Valencia } \\
\text { Late }\end{array}$ & $\begin{array}{l}\text { Rhode } \\
\text { Red Val. }\end{array}$ & Midknight Valencia & Rio Red & \\
\hline AG14 & 3 & - & 9 & 19 & 20 & - & - & 39 & 90 \\
\hline ATC09 & - & 1 & 2 & 3 & 14 & - & 1 & 2 & 23 \\
\hline CAC33 & 11 & 21 & - & 4 & 2 & 9 & 2 & 21 & 70 \\
\hline CAGG9 & 6 & - & - & 2 & - & - & - & 12 & 20 \\
\hline CAT01 & - & - & - & - & 5 & 23 & - & 8 & 36 \\
\hline CAT02 & 19 & - & 5 & 9 & - & - & 4 & 21 & 58 \\
\hline TAA01 & - & - & - & - & 13 & - & 4 & 8 & 25 \\
\hline TAA03 & 6 & 23 & - & - & 27 & 22 & 5 & 4 & 87 \\
\hline TAA41 & - & 29 & 11 & 7 & - & 12 & - & 15 & 74 \\
\hline TAA45 & - & - & - & - & - & - & - & - & - \\
\hline TAA 52 & 3 & 2 & - & 5 & - & - & - & - & 10 \\
\hline
\end{tabular}


482

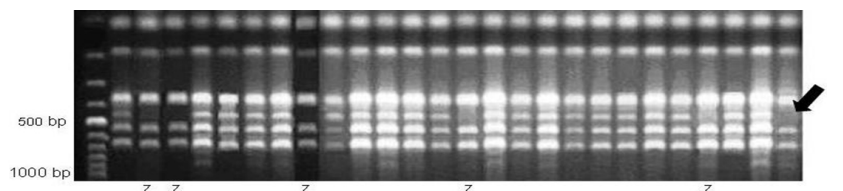

Fig. 1. Microsatellite TAA03 alleles banding pattern on 2\% agarose gel Lane M: 100 bp molecular marker (Invitrogen); lanes 1 - 24 tested seedlings; lane R: 'Robinson' mandarin; lane MV: 'Midknight Valencia' orange; Z: zygotic genotypes

Results of this study agree with those of the previous studies. Female parents, 'Fremont' and 'Robinson' mandarins, and male parents of oranges had a genetic similarity range of $0.79-0.86$ and $0.81-0.90$, respectively, while these two mandarins had lower genetic similarity value, 0.72 and 0.73, respectively. Fang and Roose (1997) mentioned that mutations in most cases may cause significant changes in tree morphology, but with corresponding small modifications in the DNA sequence, which are therefore difficult to detect. Similarly, Luro et al. (2000) reported that oranges had an origin from a single parent and they are difficult to discriminate. Novelli et al. (2000) and Novelli et al. (2006) also reported that, despite considerable morphological differences, there is little RFLP, RAPD, and SSR polymorphism. Based on SSR markers, Cao et al. (2007) failed to detect differences among 16 Satsuma mandarins and, therefore, the possible mutation origin of these variants. Zygotic seedlings obtained from 'Fremont' and 'Robinson' mandarins as female parents and oranges as male parents had a similarity value of 0.86 and 0.95 , respectively. The seedlings always have a higher similarity value with their maternal parents, which indicates decreasing genetic background thereby, increasing inbreeding which may cause lower tree performance under various environmental conditions (Fehr, 1993). Collectively, the results from this study suggest that the analysis of molecular markers may contribute significantly to citrus breeding programs.

\section{Conclusions}

This study demonstrated that the pollinators studied influenced the frequency of nucellar seedlings as detected by SSR markers. In the whole $F_{1}$ population, using grapefruit as the male parent resulted in more hybrid seedlings ratio than other orange male parents. The use of 'Midknight Valencia' as the male parent increased nucellar seedlings and was not found to be useful for hybridization. This result suggests that deliberate analysis of various combinations of parents is essential in citrus breeding programs. The use of SSR markers is an effective method to identify nucellar seedlings as being genetically identical to their maternal parent and may significantly contribute to breeding programs by decreasing the space and time needed to develop new cultivars.

\section{Acknowledgements}

We would like to thank the Turkish National Scientific and Technological Council for financial support (Project number: TOVAG 108O311). We also thank Dr. Salih Kafkas for his advice and comments during the study. Finally, we thank Dr. Sedat Serçe for his suggestions during the preparation of the manuscript.

\section{References}

Albach RF, Redman GH (1969). Composition and inheritance of flavanones in Citrus fruit. Phytochemistry 8:127-143.

Anderson CM, Castle WS, Moore GA (1991). Isozymic identification of zygotic seedlings in Swingle citrumelo Citrus paradisi_Poncirus trifoliata nursery and field populations. J Am Soc Hort Sci 116:322-236.

Ashari S, Aspinall D, Sedgley M (1988). Discrimination of zygotic and nucellar seedlings of five polyembryonic citrus rootstocks by isozyme analysis and seedling morphology. J Hort Sci 63:695-703.

Asins MJ, Herrero R, Pina JA, Carbonell EA, Navarro L (1996). Genetic relationships in Citrus and related genera. Eighth Meeting of the International Society of Citriculture, 12-17 May 1996, Sun City Resorth-South Africa 248-253 p.

Barkley NA, Roose ML, Krueger RR, Federici CT (2006). Assessing genetic diversity and population structure in a citrus germplasm collection utilizing simple sequence repeat markers (SSRs). Theor Appl Genet 112:1519-1531.

Bastianel M, Schwarz SF, Colleta-Filho HD, Lin LL, Machado MA, Koller OC (1998). Identification of zygotic and nucellar tangerine seedlings (Citrus spp.) using RAPD. Genet Mol Biol 21:123-127.

Cameron JW (1979). Sexual and nucellar embryony in $F_{1}$ hybrids and advanced crosses of Citrus and Poncirus. J Am Soc Hort Sci 104:408-410.

Cameron JW, Soost RK (1980). Mono and poly embryony among tetraploid Citrus hybrids. HortSci 15:730-731.

Cao QQ, Meng HJ, Wen XP, Yi HL, Deng XX (2007). Genetic diversity of male sterile and low fertility germplasm of Citrus revealed using SSR markers. Chin J Agr Biotec 4:99-104.

Cristofani M, Machado MA (1998). Utilização de marcadores moleculares na identificação de plântulas zigóticas e nucelares em sementeira de limão 'Cravo'. Laranja 19:147158.

De Lange JH, Vincent AP (1977) Citrus breeding: new techniques in stimulation of hybrid production and identification of zygotic embryos and seedlings. Second Meeting of the International Society of Citriculture, Vol. 2, FloridaUSA 589-595 p.

Dhillon RS, Kaundal GS, Cheema SS (1993). Nucellar embryony for propagating Citrus. Indian Hort 38:44-45.

Dice LR, (1945). Measures of the amount of ecologic association between species. Ecology 26:297-302.

Doyle JJ, Doyle JL (1990). Isolation of plant DNA from fresh 
tissue. Focus 12:13-15.

Esen A, Soost RK (1974). Inherence of browning of youngshoot extracts of Citrus. J Hered 65:97-100.

Fang DQ, Roose ML (1997). Identification of closely related Citrus cultivars with Inter Simple Sequence Repeat Markers. Theor Appl Genet 95:408-417.

Fehr WR (1993). Principles of Cultivar Development. Vol. 1, Macmillian Publishing Company, USA.

Frost HB, Soost RK (1967). Seed reproduction: Development of gametes and embryos, 290-324 p. In: Reuther W, Batchelor LD, Webber HJ (Eds.). The Citrus Industry. University of California Press, Berkeley, USA.

Furr JR, Reece PC (1946). Identification of hybrid and nucellar citrus seedlings by a modification of the rootstock color test. J Am Soc Hort Sci 48:141-146.

Garcia R, Asin MJ, Forner J, Carbonell EA (1999). Genetic analysis of apomixes in Citrus and Poncirus by molecular markers. Theor Appl Genet 99:511-518.

Gulsen O, Roose ML (2001). Lemons: Diversity and relationships with selected Citrus genotypes as measured with nuclear genome markers. J Am Soc Hort Sci 126:309-317.

Gulsen, O, Shearman RC, Vogel KP, Lee DJ, Baenziger PS, Heng-Moss TM, Budak H (2005). Nuclear genome diversity and relationships among naturally occurring buffalograss genotypes determined by SRAP markers. Hortsci 40:537541.

Hearn CJ (1973) Recently released cultivars and the development of new hybrids of Citrus fruits in Florida. First Meeting of the International Society of Citriculture, MurciaSpain, 81-85 p.

Hirai M, Kozaki I, Kajiura I (1986). The rate of spontaneous inbreeding of trifoliate orange and some characteristics of the inbred seedlings. Jpn J Breed 36:138-146.

Hodgson RW (1967). Horticultural varieties of citrus, 431-591 p. In: Reuther W, Batchelor LD, Webber HJ (Eds.). The Citrus Industry. University of California Press, Berkeley, USA.

Hwang AS, Yeuh CS (1989). Studies on polyembryony and improvement of breeding efficiency of oranges. Tai Agr Res Ins Spe Pub 27:28-38.

Hwang AS (1991). The polyembryony and identification of zygotic seedlings of lemon. J Agr Res China 40:225-232.

Iglesias L, Lima H, Simon JP (1974). Isozyme identification of zygotic and nucellar seedlings in Citrus. J Hered 65:81-84.

Khan IA, Roose ML (1988). Frequency and characteristics of nucellar and zygotic seedlings in three cultivars of trifoliate orange. J Amer Soc Hort Sci 113:105-110.

Kijas JMH, Thomas MR, Fowler JCS, Roose ML (1997). Integration of trinucleotide microsatellites into a linkage map of citrus. Theor Appl Genet 94:701-706.

Luro F, Rist D, Ollitrault P (2000). Sequence tagged microsatellies polymorphism: An alternative tool for cultivar identification and evaluation of genetic relationships in Citrus. Ninth Meeting of the International Society of Citriculture,
7-8 December 2000, Florida-USA, 170-171 p.

Moore GA, Castle WS (1988). Morphological and isozymic analysis of open-pollinated Citrus rootstock populations. J Hered 79:59-63.

Mullis K, Fallona S, Schraf S, Saiki R, Horn G, Erlich H (1986). Specific enzymatic amplification of DNA in vitro: the polymerase chain reaction. Cold Spring Harbor Symp Quant Biol 51:263-273.

Nakatani M, Ikeda I, Kobayashi S (1984). Difference of the number of embryos per seed in varieties and strains of sweet oranges (Citrus sinensis Osbeck). Bull Fruit Tree Res Stn E5:35-42.

Nicolosi E, Deng ZN, Gentile A, La Malfa S, Continella G, Tribulato E (2000). Citrus phylogeny and genetic origin of important species as investigated by molecular markers. Theor Appl Genet 100:1155-1166.

Nishiura M, Iwasaki T (1980). Number of seedling per seed and numbers of gametic and nucellar seedlings from satsuma by cross-pollination. Bull Fruit Tree Res Stn B3:1-10.

Novelli VM, Machado MA, Lopes CR (2000). Isoenzymatic polymorphism in Citrus spp. and Poncirus trifoliata (L.) Raf. (Rutaceae). Gen and Mol Bio 23:163-168.

Novelli VM, Cristofani M, Souza AA, Machado MA (2006). Development and characterization of polymorphic microsataellite markers for the sweet orange (Citrus sinensis L. Osbeck). Gen and Mol Bio 29:90-96.

Oliveira AC, Garcia AN, Cristofani M, Machado MA (2002). Identification of citrus hybrids through the combination of leaf apex morphology and SSR markers. Euphytica 128:397403.

Pang XM, Hu CG, Deng XX (2007). Polygenetic relationship within Citrus and related genera as inferred from AFLP markers. Gen Res and Crop Evol 54:429-436.

Pieringer AP, Edwards GJ (1967). Identification of nucellar and zygotic citrus seedlings by infrared spectroscopy. J Am Soc Hort Sci 86:226-234.

Rao MN, Soneji JR, Chen C, Huang S, Gmitter FG (2008). Characterization of zygotic and nucellar seedlings from sour orange-like Citrus rootstock candidates using RAPD and EST-SSR markers. Tree Gen and Genom 4:113-124.

Rohlf FJ (1993). NTSYS-pc, numerical taxonomy and multivarite analysis system, version 1.18. New York, Exeter, Setauket.

Roose ML, Traugh SN (1988). Identification and performance of Citrus trees on nucellar and zygotic rootstocks. J Am Soc Hort Sci 113:100-105.

Ruiz C, Breto MP, Asins MJ (2000). A quick methodology to identify sexual seedlings in citrus breeding programs using SSR markers. Euphytica 112:89-94.

Shareefa M, Singh AK, Manish S, Dubey AK (2009). Differentiation of nucellar and zygotic seedlings in citrus using ISSR markers. Indian J of Agr Sci 79:884-889.

Soares-Filho W dos S, Lee LM, da Cunha Sobrinho AP (1995). 
484

Influence of pollinators on polyembryony in Citrus. Acta Hortic 403:256-265.

Soost RK, Williams TE, Torres AM (1980). Identification of nucellar and zygotic seedlings of Citrus with leaf isozymes. HortSci 15:728-729.

Soost RK, Roose M (1996). Citrus, 257-323 p. In: Jules J, Moore JN (Eds.). Fruit breeding: tree and tropical fruits. John Wiley and Sons, Inc., New York, USA.

Spiegel-Roy P, Bardi A, Shani A (1977). Peroxidase isozymes as a tool for early separation of nucellar and zygotic citrus seedlings. Second Meeting of the International Society of Citriculture, Vol. 2, Florida-USA, 619-624 p.

Stanley WL, Jurd L (1971). Citrus coumarins. J Agr Food Chem 19:1106-1110.

Tatum JH, Berry RE, Hearn CJ (1974). Characterization of Citrus cultivars and separation of nucellar and zygotic seedlings by thin layer chromatography. Proc Florida State Hort Soc $87: 75-81$.

Tusa N, Abbate L, Ferrante S, Lucretti S, Scarano MT (2002). Identification of zygotic and nucellar seedlings in Citrus interploid crosses by means of isozymes, flow cytometry and ISSR-PCR. Cel and Mol Bio Letters 7:703-708.
Uzun A, Yesiloglu T, Aka-Kacar Y, Tuzcu O, Gulsen O (2009). Genetic diversity and relationships within Citrus and related genera based on sequence related amplified polymorphism markers (SRAPs). Sci Hort 121:306-312.

Vilarinhos AD, Pereira VCH, Soares-Filho W dos S, Nickel O, Oliveira RP (2000). Marcadores RAPD na avaliação da diversidade genética e na identificação de híbridos interespecíficos de Citros. Rev Bras de Frut 22:14-19.

Weinbaum SA, Cohen E, Spiegel-Roy P (1982). Rapid screening of 'Satsuma' mandarin progeny to distinguish nucellar and zygotic seedlings. Hort Sci 17:239-240.

Yun JU, Yang HB, Jung YH, Yun SH, Kim KS, Kim CS, Song KJ (2007). Identification of zygotic and nucellar mandarin seedlings using randomly amplified polymorphic DNA. Hort Environ Bio 48:171-175. 